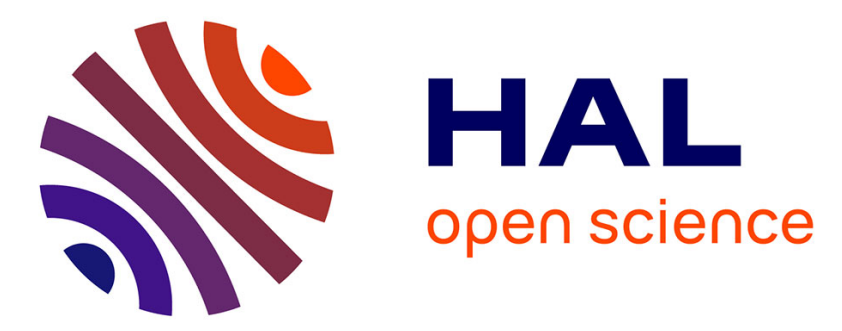

\title{
Purification, partial characterization, and reactivity with aromatic compounds of two laccases from Marasmius quercophilus strain 17
}

\author{
Anne Marie Farnet da Silva, S Criquet, S Tagger, G Gil, J. Le Petit
}

\section{To cite this version:}

Anne Marie Farnet da Silva, S Criquet, S Tagger, G Gil, J. Le Petit. Purification, partial characterization, and reactivity with aromatic compounds of two laccases from Marasmius quercophilus strain 17. Canadian Journal of Microbiology, 2000, 46 (3), pp.189-194. 10.1139/w99-138 . hal-02071815

\section{HAL Id: hal-02071815 https://hal.science/hal-02071815}

Submitted on 18 Mar 2019

HAL is a multi-disciplinary open access archive for the deposit and dissemination of scientific research documents, whether they are published or not. The documents may come from teaching and research institutions in France or abroad, or from public or private research centers.
L'archive ouverte pluridisciplinaire HAL, est destinée au dépôt et à la diffusion de documents scientifiques de niveau recherche, publiés ou non, émanant des établissements d'enseignement et de recherche français ou étrangers, des laboratoires publics ou privés. 


\title{
Purification, partial characterization, and reactivity with aromatic compounds of two laccases from Marasmius quercophilus strain 17
}

\author{
A.M. Farnet, S. Criquet, S. Tagger, G. Gil, and J. Le Petit
}

\begin{abstract}
Two isozymes of laccase were obtained from an induced liquid culture of Marasmius quercophilus with $p$-hydroxybenzoic acid as the inducer. Both the constitutive and the induced isozyme have a molecular mass of $60 \mathrm{kDa}$ as determined by polyacrylamide gel electrophoresis. Using isoelectric focusing, we found three isozymes with the constitutive enzyme (pI 4, 4.2, 4.4) and four of the induced form (pI 4.75, 4.85, 4.95, 5.1). We observed certain differences between these two isozymes; the specific activity of the induced isozyme was twice as high, and two optimum $\mathrm{pH}$ levels (5 and 6) were observed with the induced isozyme (only one, $\mathrm{pH} \mathrm{5}$, for the constitutive isozyme). However, both of these enzymes have the same thermal stability and the same temperature for their highest activity $\left(80^{\circ} \mathrm{C}\right)$. Furthermore, the reactivity of both these enzymes with aromatic compounds was similar. The use of mediators extended the oxidized substrate range of the laccases studied. Various products of degradation were observed, depending on the mediator used. When laccase was used alone, the decrease of the signal corresponding to the aromatic cycle, without any formations of other peaks at different wavelengths, suggested polymerisation of aromatic compounds.
\end{abstract}

Key words: laccase, Marasmius quercophilus, mediator, phenol degradation.

\begin{abstract}
Résumé : Deux isozymes de laccases ont été obtenues à partir d'une culture liquide induite de Marasmius quercophilus en utilisant l'acide $p$-hydroxybenzoïque comme inducteur. Les isozymes constitutives et induites ont toutes deux un poids moléculaire de $60 \mathrm{kDa}$ mesuré en électrophorèse sur gel de polyacrylamide. En électrofocalisation, nous avons observé trois isozymes pour l'enzyme constitutive ( $\mathrm{pI} 4,4.2,4.4)$ et quatre pour l'isozyme induite (pI 4.75, 4.85, 4.95, 5.1). Nous avons observé certaines différences entre ces deux isozymes; l'activité spécifique de l'isozyme induite était deux fois plus importante que celle de l'isozyme constitutive et deux pH optimum (5 et 6) ont été notés pour l'isozyme induite (seulement un, $\mathrm{pH} 5$, pour l'isozyme constitutive). Les deux enzymes avaient la même stabilité thermique et la même température d'activité maximale $\left(80^{\circ} \mathrm{C}\right)$. De plus, la réactivité de ces deux laccases vis-à-vis des composés aromatiques était semblable. L'utilisation de médiateurs a augmenté la gamme des substrats oxydés par les laccases étudiées. Différents produits de dégradation ont été observés selon le médiateur utilisé. Quand seule la laccase est utilisée, la diminution du signal correspondant au composé aromatique et l'absence d'autres pics à différentes longueurs d'ondes, suggèrent une polymérisation des composés aromatiques.
\end{abstract}

Mots clés : laccase, Marasmius quercophilus, médiateurs, dégradation des phénols.

\section{Introduction}

Marasmius quercophilus is a white-rot fungus which colonizes evergreen oak litter, a typical Mediterranean ecosystem. The potential role of this basidiomycete in litter biodegradation has been described in a previous study (Tagger et al. 1998). This fungus is particularly involved in ligninolysis

A.M. Farnet, ${ }^{1}$ S. Criquet, S. Tagger, and J. Le Petit. Laboratoire de Microbiologie, Service 452, Institut Méditerranéen d'Ecologie et de Paléoécologie, Faculté des Sciences et Techniques de St Jérôme, 13397, Marseille, CEDEX 20, France.

G. Gil. Laboratoire de Bioconversion, Service 532, U.M.R. C.N.R.S 6517, Faculté des Sciences et Techniques de St Jérôme, 13397, Marseille, CEDEX 20, France.

${ }^{1}$ Author to whom all correspondence should be addressed. because of its production of laccases (EC 1.10.3.2.). The role of these phenoloxidases in ligninolysis has already been described by several authors, such as Bourbonnais et al. (1997), using kraft lignin as a lignin model. Ander and Eriksson (1976) have also demonstrated that laccases were essential in lignin degradation by Sporotrichum pulverulentum, as did Eggert et al. (1997) with Pycnoporus cinnabarinus. This enzyme belongs to the family of blue copper oxidases, which includes ceruloplasmine and ascorbate oxidase. Laccases have provoked considerable interest in biotechnologies such as kraft pulp bleaching or degradation of aromatic pollutants because of the reactions they catalyze. They oxidize aromatic compounds such as ortho-, paradiphenols, and aminophenols, and simultaneously reduce oxygen to water. Recently, authors have reported that the use of mediators such as 2,2'-azinobis(3-ethylbenzthiazoline-6sulfonate) (ABTS), promazine, Remazol brilliant blue, or 1hydroxybenzotriazole (HBT), extended the substrate range of laccases (Xu et al. 1997; Bourbonnais et al. 1998). These 
mediators seem to act as diffusible lignin-oxidizing agents, since laccase is a large molecule which can not easily enter the plant cell wall structure because of steric hindrance. The purpose of our study was to describe the biochemical characteristics of two laccases from $M$. quercophilus. Furthermore, we investigated the enzymatic potential of both these enzymes by testing various aromatic compounds (monolignols, hydrolysable tannins). We also studied the effect of two mediators (ABTS and HBT) on the laccase degradation potential. The two isozymes studied included a constitutive and an induced enzyme. In a previous study (Farnet et al. 1999), the induction was performed using $p$-hydroxybenzoic acid as described. Numerous aromatic compounds have already been reported as inducers of laccases (Rogalski and Leonowicz 1992; Vasdev and Kuhad 1994). Moreover, we wanted to compare these two isozymes in their reactivity on aromatic compounds or in their biochemical characteristics. This may explain their respective roles in the laccase enzymatic system of M. quercophilus.

\section{Material and methods}

\section{Isolation of the strain}

Marasmius quercophilus strain 17 was isolated from La Gardiole de Rians, Var, France, using the rhizomorphic form of the fungus. A fungal cap culture was first made on a $20 \mathrm{~g} \cdot \mathrm{L}^{-1}$ malt-agar medium (Bio Mérieux, Marcy l'Etoile, France), and $50 \mathrm{mg} \cdot \mathrm{L}^{-1}$ chloramphenicol (Sigma). Next, the pure mycelial culture obtained was used to inoculate an agar medium (whole wheat flour, $20 \mathrm{~g} \cdot \mathrm{L}^{-1}$ ) favouring rhizomorph production. Finally, one rhizomorph was used to inoculate a malt-agar plate to obtain a pure dicaryotic culture.

\section{Culture conditions}

Precultures were performed in 200-mL Erlenmeyer flasks containing $50 \mathrm{~mL}$ of malt extract medium $\left(20 \mathrm{~g} \cdot \mathrm{L}^{-1}\right)$ in static conditions at $28^{\circ} \mathrm{C}$. They were inoculated with a plug of agar culture $\left(15 \mathrm{~g} \cdot \mathrm{L}^{-1}\right)$ with malt extract $\left(20 \mathrm{~g} \cdot \mathrm{L}^{-1}\right)$. These liquid precultures were used to inoculate two 2000-mL Erlenmeyer flasks with $500 \mathrm{~mL}$ of malt extract medium $\left(20 \mathrm{~g} \cdot \mathrm{L}^{-1}\right), 0.05 \%$ Tween 80 , $5 \mathrm{mg} \cdot \mathrm{L}^{-1} \mathrm{CuSO}_{4}$, and $500 \mathrm{mg} \cdot \mathrm{L}^{-1} p$-hydroxybenzoic acid. They were incubated at $28^{\circ} \mathrm{C}$ for five days under axial shaking. Enzyme activity was measured by following the oxidation of syringaldazine (N,N'-bis-(3,5-dimethoxy-4-hydroxybenzylidene)hydrazine), which leads to its quinone $\left(\varepsilon^{\mathrm{M}}: 6.5 \times 10^{4} \cdot \mathrm{M}^{-1} \cdot \mathrm{cm}^{-1}\right)$ at $525 \mathrm{~nm}$ (Harkin and Obst 1973) on a Kontron Uvikon 860 spectrophotometer. The assay contained $500 \mu \mathrm{L}$ of the filtered culture medium, $2.5 \mathrm{~mL}$ of $0.1 \mathrm{M}$ phosphate buffer $\mathrm{pH} 5.7$, and $10 \mu \mathrm{L}$ of syringaldazine $0.6 \%$ $(\mathrm{w} / \mathrm{v})$, diluted in methanol. The blank consisted of $500 \mu \mathrm{L}$ of the filtered culture medium, and $2.5 \mathrm{~mL}$ of the same phosphate buffer.

\section{Purification of the two laccase isozymes}

Cultures were filtered on a $2.7-\mu \mathrm{m}$ glass microfibre filter GF/D (Whatman, U.K.). These filtered media were concentrated on an ultrafiltration cell, model 8200 (Amicon, Beverly, Mass.) until the volume reached $15 \mathrm{~mL}$. The membrane used (Amicon), was rated at $10 \mathrm{MW}(10 \mathrm{kDa})$ cut-off. This membrane was rinsed with an additional volume of $1 \mathrm{~mL}$ of $0.1 \mathrm{M}$ phosphate buffer, $\mathrm{pH} 5.7$, to remove any bound laccases from its surface. This sample was then loaded on a Mono Q column. A step gradient system of $\mathrm{NaCl}$ in Tris- $\mathrm{HCl}$ buffer $10 \mathrm{mM}$ pH $6(0,0.2,0.4,1)$ was used to elute active fractions. Laccase activity was detected using syringaldazine. The active fractions that eluted as one peak were pooled and ultrafiltered as described before.

\section{Effects of $\mathbf{p H}$ and temperature on laccase activity}

Laccase activity was detected as previously described using 15 $\mu \mathrm{g}$ of each purified fraction. Acetate buffer at $0.1 \mathrm{M}$ was used for $\mathrm{pH}$ range from 4 to 5 , and $0.1 \mathrm{M}$ phosphate buffer was used for $\mathrm{pH}$ range from 5.7 to 8 . The optimum temperature for laccase activity was determined using $15 \mu \mathrm{g}$ of each purified fraction in $0.1 \mathrm{M}$ acetate buffer at $\mathrm{pH}$ 5. Six temperatures were tested: 30, 40, 50, 60, 70 , and $80^{\circ} \mathrm{C}$. The thermal stability of laccase activity was studied using the temperature mentioned above after several incubation times $(1,2,3,5,7,9,24$, and $36 \mathrm{~h})$. Laccase activity was also measured using $15 \mu \mathrm{g}$ of each purified fraction in $0.1 \mathrm{M}$ acetate buffer at $\mathrm{pH} 5$.

\section{Electrophoresis analysis}

Sodium dodecyl sulfate (SDS) - polyacrylamide gel electrophoresis (PAGE) was carried out according to Laemmli (1970) using a $4 \%$ stacking gel and $7.5 \%$ separating gel at $220 \mathrm{~V}$ with the Mini-Protean II electrophoresis cell (Bio-Rad). Molecular masses of the two laccase isozymes were determined using a high-range molecular mass prestained standard (Bio-Rad). Protein bands were revealed using the Coomassie blue standard method. IEF analysis were performed on Servalyt Precotes polyacrylamide gels (Serva, 3-6 pH gradient, $150 \mu \mathrm{m}, 125 \times$ $125 \mathrm{~cm}, \mathrm{pI}$ markers) according to the manufacturer. Gel staining was performed using $p$-phenylenediamine at a final concentration of $0.1 \%(\mathrm{v} / \mathrm{v})$ in $0.1 \mathrm{M}$ acetate buffer, $\mathrm{pH} \mathrm{5}$, during $30 \mathrm{~min}$.

\section{HPLC analysis of aromatic compound degradation}

HPLC system was equipped with a C18 column (Merck, $4.6 \times$ $250 \mathrm{~mm}$ ) in the following gradient system: solvent A, water/trifluoro acetic acid $0.1 \% /$ methanol $90 / 10 \mathrm{v} / \mathrm{v}$; solvent $\mathrm{B}$ water/trifluoro acetic acid $0.1 \% /$ methanol $5 / 95 \mathrm{v} / \mathrm{v}$; gradient $=0-25 \mathrm{~min} \mathrm{~A} 100 \%$ to B $100 \%$; 25 to $40 \mathrm{~min} \mathrm{~B} 100 \%$ (flow rate $1 \mathrm{~mL} \cdot \mathrm{min}^{-1}$; detection at $270 \mathrm{~nm}$ ). The aromatic compound degradation was assayed using a reaction mixture $(10 \mathrm{~mL})$ containing $1 \mathrm{mM}$ ABTS or HBT, $1000 \mathrm{mg} \cdot \mathrm{L}^{-1}$ aromatic compound, and $5 \mathrm{U}$ of the laccase isozyme studied (constitutive or induced) in $0.1 \mathrm{M}$ acetate buffer $\mathrm{pH}$ 5. The same reaction was performed without mediators. Controls with only ABTS or HBT with laccase, and using ABTS or HBT with the aromatic compound but without laccase, were also used. Samples were collected at 0,2 , and $4 \mathrm{~h}$, and $20 \mu \mathrm{L}$ of each sample were injected in the HPLC system.

\section{Results and discussion}

A one-step purification using ion exchange chromatography allowed us to separate the two laccase isozymes (Fig. 1). The purity of these enzymes was shown on SDSPAGE, where each one of them was resolved as a single band (Fig. 2). We found a molecular mass of $60 \mathrm{kDa}$ for both the induced and the constitutive forms. In a previous study, we observed a difference of migration in nondenaturing conditions (Farnet et al. 1999); the constitutive isozyme had the highest molecular weight. This may be due to various degrees of glycosylation of the protein. Most laccases have molecular masses ranging from 60 to $140 \mathrm{kDa}$ (Thurston 1994; Binz and Canevascini 1997). However, a previous study in our laboratory has shown that the laccase from another $M$. quercophilus strain (strain C30) had a different molecular mass, measuring $63 \mathrm{kDa}$ (data unpublished). This may be explained by the fact that strain C30 and strain 17 under study were collected in two different areas at the site of La Gardiole de Rians. Other strains isolated from various distant sites may exhibit new isoenzyme profiles 
Fig. 1. The chromatogram of the two laccase isozymes from Marasmius quercophilus with Mono Q ion exchange chromatography. The $\mathrm{NaCl}$ step gradient system used is shown ( $\cdots \cdot)$ as well as laccase activity $(\square)$ and protein concentration ( $\square$ ). The peaks of the two laccases are labelled $\mathrm{C}$ and I for the constitutive and the inducible isozymes, respectively.

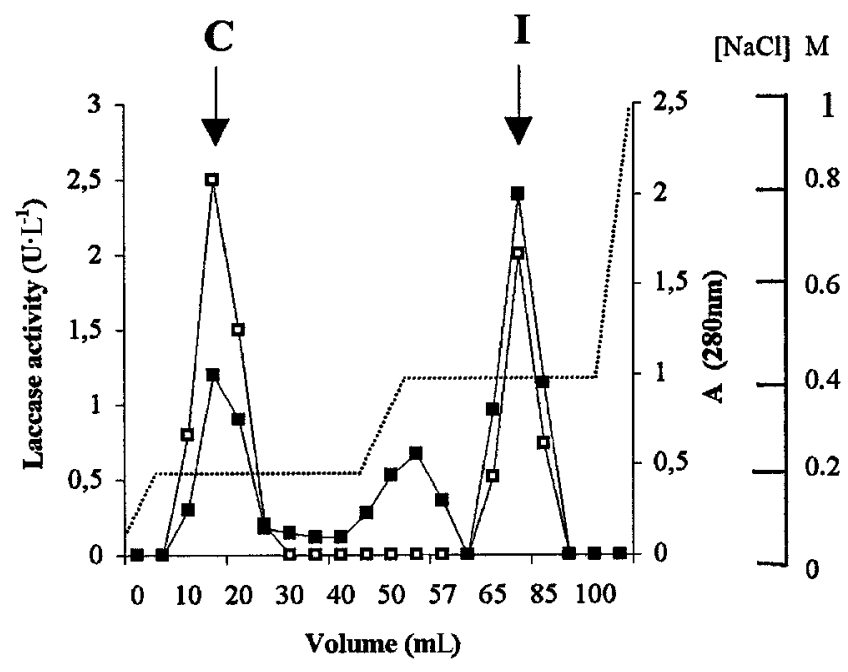

Fig. 2. SDS-PAGE of the purified extracellular laccases. The same band was observed for the constitutive and the induced isozyme. Molecular mass markers are shown in the left lane.

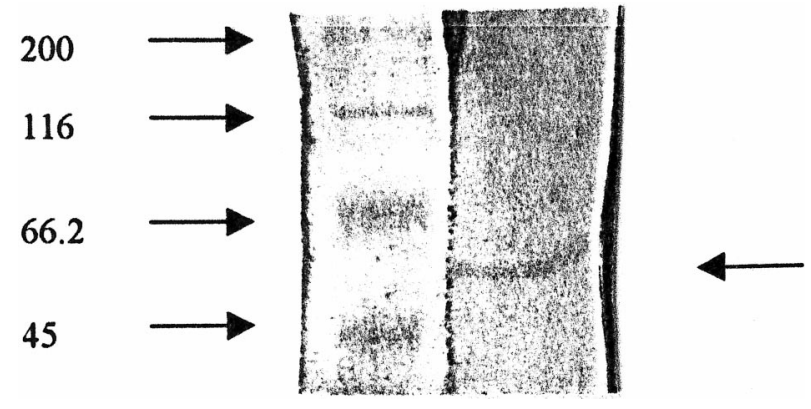

depending on the geographical areas where they are collected. Many studies have already described this phenomenon (Kerrigan and Ross 1988; Dupré et al. 1993; Sagawa et al. 1993). Authors have successfully distinguished the strains studied depending on the crop localization using their laccase zymograms. The two isozymes under study were monomeric enzymes. These are common properties for laccases. These enzymes are indeed composed of only one subunit, except in the case of the laccase from Podospora, where four subunits were found (Reinhammar and Malmström 1981). Laccase molecular properties are indeed quite homogenous; the typical laccase is a monomeric enzyme with a molecular mass ranging from 60 to $80 \mathrm{kDa}$ with $10 \%-15 \%$ of carbohydrates.

In our study, the presence of other laccase isozymes was demonstrated using the isoelectric focusing experiment (Fig. 3). We also used syringaldazine to check for the staining of the gel, since this substrate is specific to laccase under the conditions of our experiment (Harkin and Obst 1973; Leonowicz and Grzywnowicz 1981). However, syringaldazine did not lead to stable staining like $p$-phenylenediamine (data not
Fig. 3. Isoelectric focusing of the two isozymes of laccase from Marasmius quercophilus revealed by $p$-phenylenediamine. Lane 1: pIs standards; lane 2: zymogram of the constitutive isozyme; lane 3: zymogram of the induced isozyme.

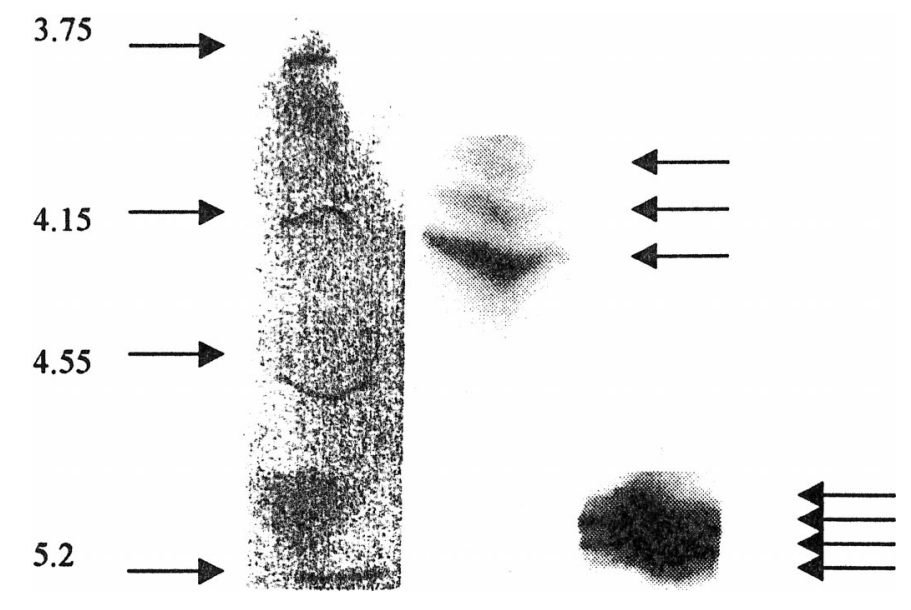

Fig. 4. The effect of $\mathrm{pH}$ on the laccase activity $\left(\mathrm{U} \cdot \mathrm{L}^{-1}\right)$ of Marasmius quercophilus was estimated with the constitutive (-) and the induced (- $\boldsymbol{\Delta}_{-}$) isozyme. All the standard deviations were below $3 \%$.

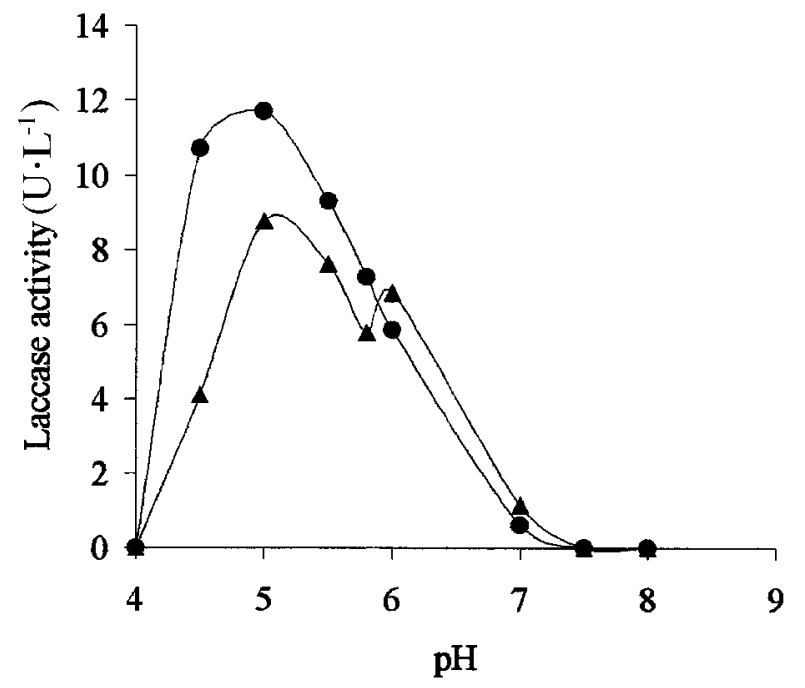

shown), and thus this last substrate was chosen for the staining of the gel. Three other isozymes (pI 4, 4.2, and 4.4) were found on the electrophoretic pattern of the pure constitutive laccase, and four other isozymes (pI 4.75, 4.85, 4.95, 5.1) were detected with the induced laccase. Several isozymes detected with isoelectric focusing have already been reported in the case of fungal laccases. For example, three isozymes were revealed by IEF from a $32-\mathrm{kDa}$ laccase fraction purified from a Botrytis cinerea strain (Pezet 1998). Different biochemical characteristics have been pointed out in this study, which may be explained by the various isozymes observed in the isoelectric focusing experiment. The specific activity of the induced isozyme was twice as high as that of the constitutive isozyme, respectively 12.35 and $6.71 \mathrm{U} \cdot \mathrm{mg}^{-1}$ protein. The optimum $\mathrm{pH}$ was 5 for both 
Fig. 5. The effect of temperature on the laccase activity $\left(U \cdot \mathrm{L}^{-1}\right)$ of Marasmius quercophilus was estimated with the constitutive (- - ) and the induced ( $\square-$ ) isozyme. All the standard deviations were below $3 \%$.

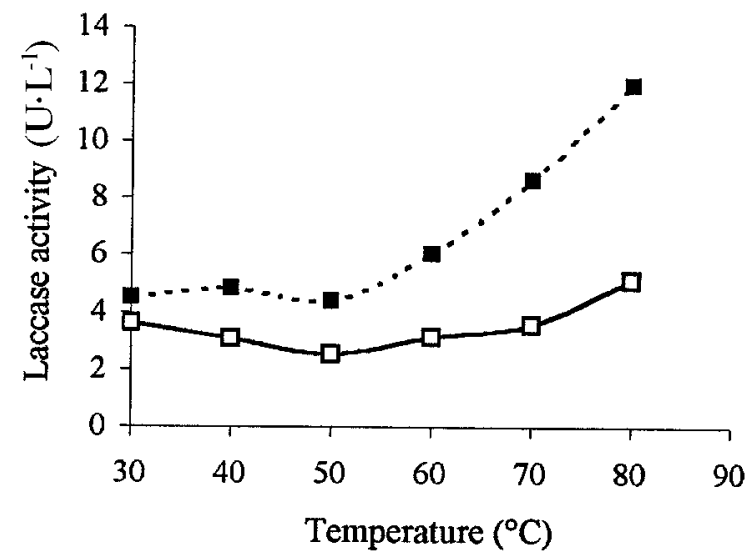

Fig. 6. The thermal stability of the two laccase isozymes of Marasmius quercophilus after various incubation times. The constitutive (A) and the induced (B) isozyme was tested using various temperatures: $40^{\circ} \mathrm{C}(-) ; 50^{\circ} \mathrm{C}(---) ; 60^{\circ} \mathrm{C}(----)$,

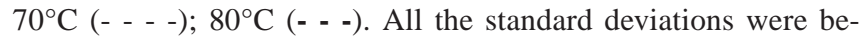
low $3 \%$.
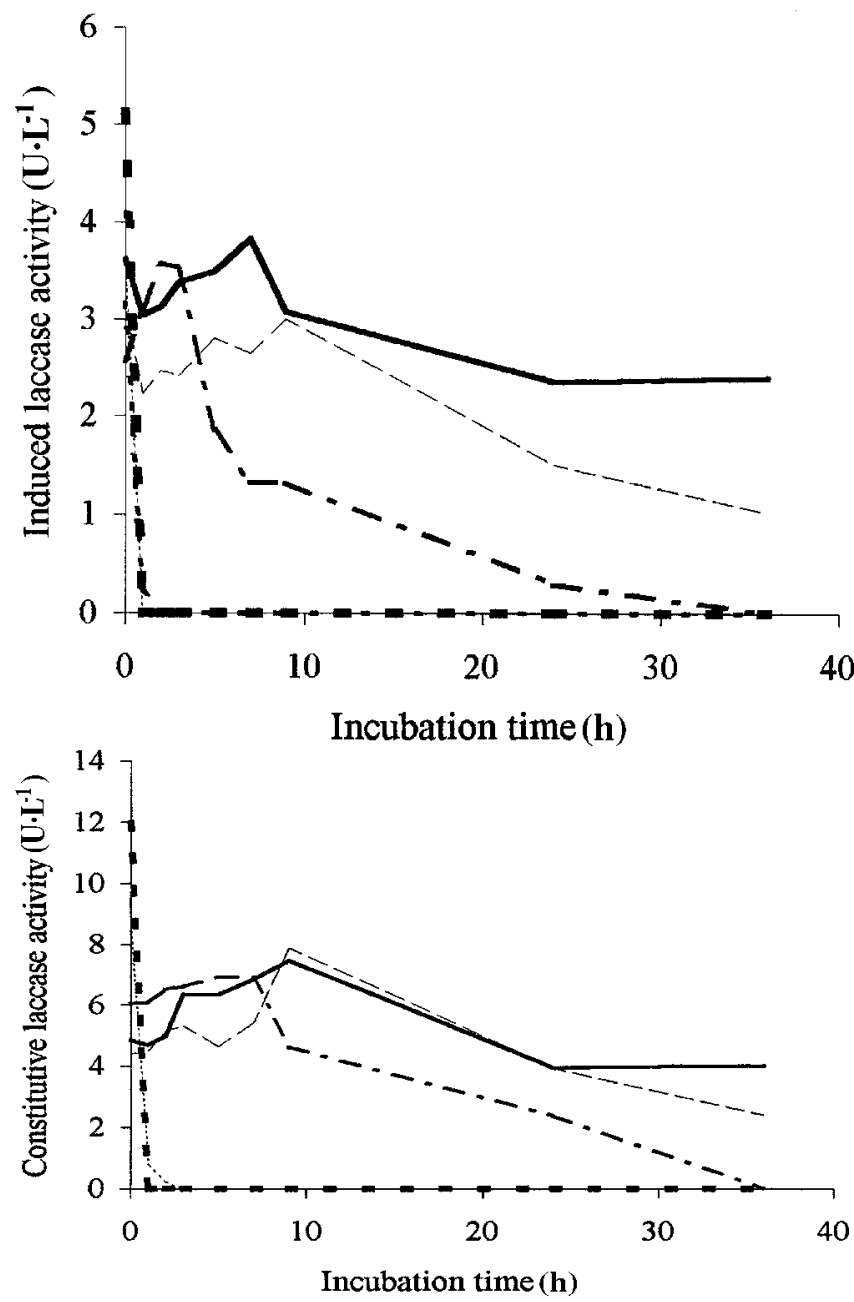

Fig. 7. The degradation of aromatic compounds with the two isozymes of Marasmius quercophilus after $4 \mathrm{~h}$ of incubation with or without mediators using RP C18 HPLC column. Results were identical regardless of isozyme used. The degradation of veratryl alcohol (A) and coniferyl alcohol (B) with ABTS (- - ), with HBT (- - ), and without mediators (-) is shown. The arrow points out the elution time of the peak of the tested aromatic compound alone.
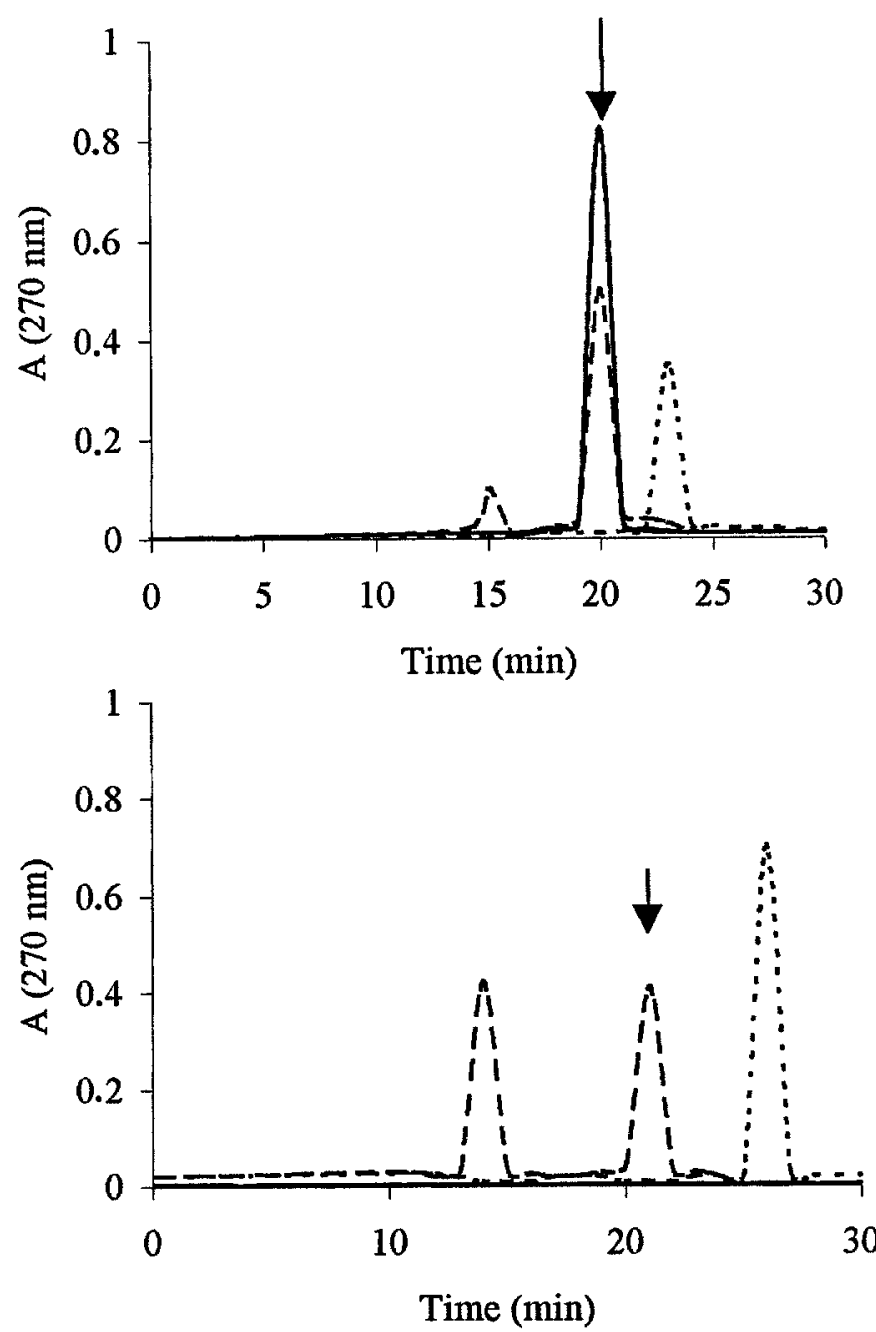

these enzymes as determined with acetate buffer, but high activity was also observed at $\mathrm{pH} 6$ with the induced isozyme (Fig. 4). However, the activity of this induced isozyme was lower at $\mathrm{pH} 6$ than at $\mathrm{pH}$ 5. Fungal laccases are generally active at low $\mathrm{pH}$ values as already reported by many authors (Bollag and Leonowicz 1984; Eggert et al. 1996; Palmieri et al. 1997). We observed that the constitutive and the induced isozymes of laccase had certain similar properties, such as thermal stability and optimum temperature. The temperature tested at the highest laccase activity was $80^{\circ} \mathrm{C}$ for both isozymes (Fig. 5), and the activity was stable after $1 \mathrm{~h}$ of preincubation at 40,50 , and $60^{\circ} \mathrm{C}$ (Figs. 6A and B). Preincubation at $40^{\circ} \mathrm{C}$ and $50^{\circ} \mathrm{C}$ strongly increased their activity, mostly in the case of the constitutive isozyme. After $1 \mathrm{~h}$ of preincubation at $70^{\circ} \mathrm{C}$, the enzymes retained only $9 \%$ and $6 \%$ of their initial activity for the constitutive and the 
induced isozyme, respectively. After $2 \mathrm{~h}$, only the constitutive form was still active (2.7\% of residual activity). No activity was detected after $1 \mathrm{~h}$ of preincubation at $80^{\circ} \mathrm{C}$ in both cases. Most fungal laccase activities have an optimum temperature ranging from 30 to $60^{\circ} \mathrm{C}$. Moreover, these enzymatic activities are not often stable between 50 to $70^{\circ} \mathrm{C}$ (Périé et al. 1998; Scherer and Fischer 1998). Thus, we found very particular properties for the laccases of M. quercophilus in terms of optimum temperature and thermal stability. These particular properties have been found only in the case of laccases isolated from a composted municipal solid waste (Chefetz et al. 1998a, 1998b), and from paper factory wastewater (Coll et al. 1993). In this last study, the laccase of basidiomycete PM1 exhibited very similar characteristics to $M$. quercophilus laccases; the optimum temperature was $80^{\circ} \mathrm{C}$, and thermal stability for a range of temperatures between $50^{\circ} \mathrm{C}-70^{\circ} \mathrm{C}$ was also observed. These biochemical properties are particularly interesting for biotechnological applications which may involve high temperatures.

All the aromatic compounds tested were degraded by the constitutive and induced isozyme of laccase, except veratryl alcohol and $p$-hydroxybenzoic acid. These aromatic compounds were not degraded without the addition of mediators, nor with constitutive isozymes, or the induced form (Fig. 7A). This result with veratryl alcohol is consistent with that observed by Bourbonnais et al. (1998). The oxidation of this non-phenolic compound was explained by the role of the dication $\mathrm{ABTS}^{2+}$, the oxidation product of laccase, as the oxidative intermediate agent. Thus the oxidation of laccase was indirect; the aromatic compound degradation is probably caused by the oxidizing intermediates produced by the laccase.

When ABTS was used as the mediator, we always observed new peaks at $270 \mathrm{~nm}$. With HBT, we did not find new peaks with gallic acid and tannic acid; we only observed the decrease of the peak of the aromatic compound. We also did not observe degradation products when only the laccase was added to the reaction mixture in the case of these two aromatic compounds. $p$-Hydroxybenzoic acid was transformed only when laccase was associated with ABTS.

In each case, the new peaks observed at $270 \mathrm{~nm}$ with ABTS and HBT differed depending on the mediator used (Fig. 7B). They were also different to those observed in the experiments involving only laccase. This would suggest that the mechanism of aromatic compound oxidation is different, depending on the oxidized mediator. These results can be explained using the experiment involving only the enzyme and the mediator; we observed new peaks which may be the oxidized form of the mediator. However, further studies are needed to clearly identify these components. These results showed that the mediators used had an effect on oxidation, and their respective action on aromatic compounds appears to be different.

The two laccase isozymes did not exhibit different properties in the degradation of aromatic compounds. The responses were identical for both the enzymes; the new peaks observed and the decrease of the peaks were the same. In this part of our study we observed only the conversion of aromatic compounds into other organic compounds. The aim of our further studies will be the identification of these products, which would allow us to investigate the mechanism of laccase oxidation at the same time. When the chromatograms showed only the decrease of the peak of the aromatic compound, this may have suggested a polymerization of aromatic compounds, which have already been described in several studies (Lundquist and Kristersson 1985; Dec and Bollag 1990). On the other hand, the cleavage of aromatic compounds by laccase has not been reported in literature before; most laccases are involved in demethylation, decarboxylation, or $\mathrm{C}_{\alpha}-\mathrm{C}_{\beta}$ cleavage in lignin model compounds (Higuchi 1993). Thus the cleavage of aromatic compounds is not likely to occur, and does not explain the decrease of the peak. However, the oligomers that may be produced in this reaction can not be detected under our experimental conditions.

It seems that, in this study, the main differences observed between the two laccase isozymes are their specific activity and the $\mathrm{pH}$ where the maximum activity is observed; the induced isozyme has a higher specific activity and exhibits a high activity for two $\mathrm{pH}$ values.

This study has shown the involvement of the laccase enzymatic system in the degradation of phenolic compounds. Furthermore, this work has also pointed out that when laccase is associated with certain mediators, its potential to degrade aromatic compounds is extended to a wider range. In a further study, we will also focus on the mechanism of the reaction by evaluating, for example, the redox potentials of the enzyme (Bonomo et al. 1998).

\section{References}

Ander, P., and Eriksson, K.E. 1976. The importance of phenol oxidase activity in lignin degradation by white-rot basidiomycete Sporotrichum pulverulentum. Arch. Microbiol. 109: $1-8$.

Binz, T., and Canevascini, G. 1997. Purification and partial characterisation of the extracellular laccase from Ophiostoma novoulmi. Curr. Micobiol. 35: 278-281.

Bollag, J.-M., and Leonowicz, A. 1984. Comparative studies of extracellular fungal laccases. Appl. Environ. Microbiol. 38: 849-854.

Bonomo, R.P., Boudet, A.M., Cozzolino, R., Rizzarelli, E., Santoro, A.M., Sterjiades, R., and Zappala, R. 1998. A comparative study of two isozymes of laccase secreted by the white-rot fungus Rigidosporus lignosus, exhibiting significant structural and functional differences. J. Inorg. Biochem. 71: 205-211.

Bourbonnais, R., Paice, M.G., Freiermuth, B., Bodie E., and Borneman, S. 1997. Reactivities of various mediators and laccases with kraft pulp and lignin model compounds. Appl. Environ. Microbiol. 63: 4627-4632.

Bourbonnais, R., Leech, D., and Paice, M.G. 1998. Electrochemical analysis of the interactions of laccase mediators with lignin model compounds. Biochem. Biophys. Acta, 1379: 381-390.

Chefetz, B., Chen, Y., and Hadar, Y. 1998a. Purification and characterization of laccase from Chaetomium thermophilium and its role in humification. Appl. Environ. Microbiol. 64: 3175-3179.

Chefetz, B., Kerem, Z., Chen, Y., and Hadar, Y. 1998b. Isolation and partial characterisation of laccase from thermophilic composted municipal solid waste. Soil Biol. Biochem. 30: 10911098.

Coll, P.M., Fernandez-Abalos, J.M., Villanueva, J.R., Santamaria, R., and Perez, P. 1993. Purification and characterization of a 
phenoloxidase (laccase) from the lignin-degradaing basidiomycete PM1 (CECT 2971). Appl. Environ. Microbiol. 59: 2607-2613.

Dec, J., and Bollag, J. 1990. Detoxification of substituted phenols by oxidoreductive enzymes through polymerisation reactions. Arch. Environ. Contam. Toxicol. 19: 543-550.

Dupré, C., Chevalier, G., Palenzona, M., and Biocca, E. 1993. Caractérisation des mycorhizes de différent Tuber par l'étude du polymorphisme enzymatique. Cryptogam. Mycol. 14: 163-170.

Eggert, C., Temp, U., and Eriksson, K.-E.L. 1996. The ligninolytic system of the white-rot fungus Pycnoporus cinnabarinus: purification and characterization of the laccase. Appl. Environ. Microbiol. 62: 1151-1158.

Eggert, C., Temp, U., and Eriksson, K.-E.L. 1997. Laccase is essential for lignin degradation by the white-rot fungus Pycnoporus cinnabarinus. FEBS Lett. 407: 89-92.

Farnet, A.M., Tagger, S., and Le Petit, J. 1999. Effects of copper and aromatic inducers on the laccases of the white-rot fungus Marasmius quercophilus. C. R. Acad. Sci. Paris, Life Sciences. 322: 499-503.

Harkin, J.M., and Obst, J.R. 1973. Syringaldazine, an effective reagent for detecting laccase and peroxidase in fungi. Experientia, 29: 381-387.

Higuchi, T. 1993. Biodegradation mechanism of lignin by whiterot basidiomycetes. J. Biotechnol. 30: 1-8.

Kerrigan, R.W., and Ross, I.K. 1988. Extracellular laccases: biochemical markers for Agaricus systematics. Mycologia, 80: 689-695.

Laemmli, U.K. 1970. Cleavage of structural proteins during the assembly of the head of bacteriophage T4. Nature, 227: 680-685.

Leonowicz, A., and Grzywnowicz, K. 1981. Quantitative estimation of laccase forms in some white-rot fungi using syringaldazine as a substrate. Enzyme Microb. Technol. 3: 5558.

Lundquist, K., and Kristersson, P. 1985. Exhaustive laccasecatalysed oxidation of a lignin model compound (vanillyl glycol) produces methanol and polymeric quinoid products. Biochem. J. 229: 277-279.
Palmieri, G., Giardina, P., Bianco, C., Scaloni, A., Capasso, A., and Sannia, G. 1997. A novel white laccase from Pleurotus ostreatus. J. Biol. Chem. 272: 31301 - 31307.

Périé, F.H., Vijay, B., Reddy, G., Blackburn, N.J., and Gold, M.H. 1998. Purification and characterisation of laccases from the white-rot basidiomycete Dichomitus squalens. Arch. Biochem. Biophys. 353: 349-355.

Pezet, R. 1998. Purification and characterization of a $32-\mathrm{kDa}$ laccase-like stilbene oxidase produced by Botrytis cinerea Pers.:Fr. FEMS Microbiol. Lett. 167: 203-208.

Reinhammar, B., and Malmström, B.G. 1981. Laccase. In Copper proteins and copper enzymes, Vol. III. Edited by R. Loitié. CRC Press Inc., Boca Raton, Fla. pp. 1-35.

Rogalski, J., and Leonowicz, A. 1992. Phlebia radiata laccase forms induced by veratric acid and xylidine in relation to lignin peroxidase and manganese-dependent peroxidase. Acta Biotechnol. 12: 213-221.

Sagawa, I., Nagata, Y., and Yanagi, S.O. 1993. Electrophoretic comparison of enzymes for the discrimination of Pleurotus species. Tech. Bull. Fac. Hortic. Chiba Univ. 47: 65-73.

Scherer, M., and Fischer, R. 1998. Purification and characterisation of laccase II of Aspergillus nidulans. Arch. Microbiol. 171: 78-84.

Tagger, S., Périssol, C., Gil, G., Vogt, G., and Le Petit, J. 1998. Phenoloxidases of the white-rot fungus Marasmius quercophilus isolated from an evergreen oak litter (Quercus ilex L.). Enzyme Microb. Technol. 23: 372-379.

Thurston, C.F. 1994. The structure and function of fungal laccases. Microbiology, 140: 19-26.

Vasdev, K., and Kuhad, R.C. 1994. Induction of laccase production in Cyathus bulleri under shaking and static culture conditions. Folia Microbiol. 39: 326-330.

Xu, H., Lai, Y.Z., Slomczynski, D., Nakas, J.P., and Tanenbaum, S.W. 1997. Mediator-assisted selective oxidation of lignin model compounds by laccase from Botrytis cinerea. Biotechnol. Lett. 19: $957-960$. 